Acta Universitatis Sapientiae, Philologica, 8, 3 (2016) 43-52

DOI: 10.1515/ausp-2016-0030

\title{
Linguistic Issues in Széchenyi's Oeuvre (Plurilingualism, Multilingualism, Mother Tongue)
}

\author{
Rita PLETL \\ Sapientia Hungarian University of Transylvania \\ Faculty of Technical and Human Sciences, Târgu-Mureş \\ Department of Applied Linguistics \\ pletlrita@freemail.hu
}

\begin{abstract}
Széchenyi studied the linguistic issue, the problems he faced during his public and literary activities with the caution and precision that characterize him. His inquiry into the question of language is marked by nuanced and precise terminology. The distinction between the notions of mother tongue and national language, as well as multilingualism and plurilingualism, are consistent throughout his work. In his conception, the mother tongue is the variety of a given language that is acquired by the speaker in the most intimate environment and through which he/she is linked with the communicational processes of the language community's social interactions. The national language in his interpretation is the cultivated variety of the mother tongue, which is the language of public life and that of bourgeois national literature as well. In language use, he propagated the principle of linguistic tolerance. He considered the use of the mother tongue a right of every nation (language community). He recognized Europe's linguistic and national diversity as a value that must be safeguarded and nurtured.
\end{abstract}

Keywords: plurilingualism, multilingualism, mother tongue, national and linguistic diversity

\section{Introduction}

Széchenyi's life work unfolded at a time when among the processes of the history of the Hungarian language and culture the issue of language became of paramount importance in the self-organization of the linguistic community in basically two respects. One of the aspects was the language policy struggle (regarding status planning), the aim of which was to make the Hungarian language official on the territory of the Kingdom of Hungary. The other was the development, codification, and elaboration of the standard variety of the Hungarian language 
as well as the development of the language of literature in connection with the standard language in the context of corpus planning (Tolcsvai Nagy 2004: 20). Széchenyi's activity can be connected to both of the above: in his work entitled Hunnia, written in 1835 and published later, he argues in favour of making the Hungarian language official; with the founding of the Academy, he created a cultural institution the mission of which was the cultivation of the Hungarian language. During the Hungarian Reform Era, the institution became part of the language codification process which had been set out by the Enlightenment. The grammar published by the Academy, A magyar nyelv rendszere [The system of the Hungarian language] (1846), considered the process of standardization complete; it projected the concept of the codified standard on the descriptive grammatical system deciding not to deal with the issues of linguistic correctness, linguistic creativity, or linguistic stratification: it only gave a systematic description (Tolcsvai Nagy 2004: 27).

The public activity of the Greatest Hungarian took place in a Central and Eastern European region, in the Habsburg Empire characterized by multilingualism, where plurilingualism could be considered a general phenomenon, characterizing everyday communicational situations. It is perceived by Széchenyi in the following way: "A felette különnemú Austriai birodalomnak igen különnemú, de egy testbe szorított része vagyunk, kisebb szövedéke a nagyobb szövedéknek." ("We are a greatly heterogeneous part of the highly heterogeneous Austrian Empire, nevertheless clenched into the same body, a smaller texture of a larger texture") or: "Otthon külön-külön nyelven szólunk, máson tanácskozunk, ismét külön nyelven járulunk a fejedelmi székhez. Uraink anyai, szivi nyelve mindezektől megint idegen" ("We speak a different language at home, we deliberate in another, while talking another in the royal court. Nevertheless, the language of the mothers and the hearts of our lords is foreign.”) (Széchenyi 1858: 67-68).

Széchenyi's oeuvre is also plurilingual. He wrote all his diaries from the very first volumes until the last entries from Döbling in German. His proportionately vast, extensive correspondence is written in German, Hungarian, English, and French, depending on the mother tongue of the recipients or on the language they had chosen. Nevertheless, his literary works addressing the nation were written in Hungarian. The deliberate choice of language in the different communicational situations is best demonstrated by his Hungarian-language works: here, the use of the mother tongue and the will to educate the nation are consistently linked. As he emphasizes in his book Hitel (Credit): “...munkám kirekesztőleg Magyarországnak, magyar rokonok számára és magyarul van írva..." ("my work is exclusively written for Hungary, for relatives of Hungary, and in Hungarian”) (Széchenyi 1832: 96). He also opposed the German translation of his works arguing that they were meant for the Hungarian nation. "Ezen értekezésnek németre fordítását legkevésbé sem tartom szükségesnek, mert az egyedül a 
magyar publikumnak azon részét illeti s illetheti, mely magyarul úgy is tud, vagy legalább tanul" ("I consider translating this thesis into German completely unnecessary as it concerns and can concern that part of the Hungarian audience that already speaks Hungarian or is learning Hungarian") (qtd by Gergely 1972: 139). However, when he wanted to reply to the pamphlet written on the initiative of the Minister of Interior Bach by Court Councillor Bernhard Meyer, but published anonymously (Visszapillantás Magyarország legutóbbi fejlődési szakaszára "A retrospect at the latest development stage of Hungary") - as he recognized the political potential of the reply -, he consciously chose the German language, although calling himself a mediocre speaker of German ("noha csak igen mediocris német vagyok") in a private letter about his plan. With his work published anonymously in London (Ein Blick auf den anonymen "Rückblick"), where he lists "a Hungarian" (Von einem Ungarn) as author, Széchenyi turns to the European public for the "Hungarian cause".

Széchenyi was faced with the language issue in his period of preparation for public engagement and while elaborating his reform programme he was forced to address this complex, complicated, and diverse question more closely. As a politician, he had to tackle the problem of multilingualism and plurilingualism, as well as the status of the Hungarian language, while as a writer he examined the possibilities of linguistic expression using a novel approach, as he designed creating the text taking into consideration the point of view of the norms of expectation of the recipients (the readers). In both cases, he approached the issue from the point of view of the success of communication: in the first case, he discussed the problem of "we do not understand each other" from the aspect of multilingualism and plurilingualism, while in the second case he examined the possibilities of forming linguistic utterances based on the fact that the meaning created in the text does not necessarily overlap in the case of the writer and of the reader. His discussion on style was the result of his examination of planned effect from the point of view of achievable effect.

His gesture that set forth his public activity - offering at the 1825 Parliament one year's income of his estate in order to establish a scientific society - is of a symbolic significance. He talked in Hungarian, thus opposing Latin linguistic traditions. With his action, he concluded the Odyssey of efforts spanning over several decades regarding the founding of a scientific society. The "philological society" he established for the cultivation of the Hungarian language created the institutional framework for one of the most important cultural processes of the era, language planning, language cultivation in a broad sense, a conscious and intentional intervention into the language and the linguistic system of values of the linguistic community (Tolcsvai Nagy 2004: 21). One and a half decades after founding the institution, he still stated that "kivételes állásunknál fogva, sem egyéb, sem máskép múködő intézet nem volt oly sürgetőleg napirenden akkor, 
mikor Académiánk fölállítaték, mint éppen Académiánk" (“due to our special situation, there was no greater need for another institution or one functioning differently at the time of the establishment of our Academy than our Academy") (Széchenyi 1925: 158).

The foundation of the Academy is linked to the complex issue of nation, nationality, and mother tongue that he discussed in detail in this period; he deliberated on the relationship between nationality (he uses this concept to designate the traits of the nation) and the language, trying to find answers to the issue of the community-building role of the mother tongue and to the way the national language defines national existence. His efforts recorded in his diaries aiming to clarify certain concepts preceded the creation of his major works and reflect the fact that he recognized the role of language in cognition and thinking, as he examined the extent to which the educated, cultivated state of language determines conceptualization as well as the relationship between "clear concepts" and the clarity, precision, and accuracy of linguistic expression. Several insights and findings resulting from his meditation on the issue of language are integrated into his works about his reform ideas (Lovakrul, Hitel, Világ, Stádium); thus, his reflections on the possibilities of linguistic expression are a constant feature of his writing career. He gives a detailed and thorough discussion of the topic in two of his works: Hunnia, which was meant to be the continuation of Stádium, and his academic speech given in 1842, and consequently published in printing.

\section{Mother tongue - national language}

His concept regarding the role of the mother tongue in the national culture is based on the finding that the national language is in an "unbreakable" relationship with national existence. In his approach, the "education" and "beautification" of the mother tongue also mean the cultivation of the nation, and that is why he states that "[nyelvünknél] drágább kincsünk nincs, minthogy csak ennek kiemelése, ennek múvelése által léphet nemzet sajátságos fényben a dísznek fokára" ("there is no dearer treasure for us than our mother tongue, as through its uplifting, its cultivation our nation can also rise to honourable heights in its peculiar light") (Széchenyi 1925: 153). That is why he considers the cultivation of the language a national cause: "a nyelv kiképzése minden nemzetnél a lehető legfontosabb ügyek közé való, bármily szilárdul és bármily szüzességi fényben álljon is ott nemzetiség és nyelv" ("the cultivation of the language is of paramount importance for every nation, no matter the stability and light of chastity the nation and language stand in") (Széchenyi 1925: 161). He also warns that language cultivation, precisely because it intervenes in the linguistic system of values of the language and of the linguistic community, needs to be prudent, it needs to take into consideration the 
characteristics of the linguistic system, its historical features, as well as the sociocultural factors that create the context for the control of linguistic processes. He supports his argument with historical experience (referring to the 1790s): we did not realize that "csinosulásunk eredetiségünknek és sajátságunknak halálos megsértésével munkálódik" ("our beautification came about with a deathly violation of our originality and peculiarities") (Széchenyi 1858: 54).

In the creation of the linguistic ideal, he considered following the patterns of other countries to be beneficial: "valamint egykor a rómainak mintául szolgált a görög, $\mathrm{s}$ e kettőnek útmutatása szerint Európának szinte minden csinosb nyelve idomult" ("once the Greek served as a model for the Roman, and following the guidance of these two, almost every classier European language changed") (Széchenyi 1858: 92). In his understanding, emphasis is on guidance, on the process in which the cultivated language approaches the linguistic ideal. He identifies as a goal to be reached: a nation cannot have a more urgent and more serious activity than to bring its language close to the accurateness of sciences, as only with a language close to these can it explain its interests in the most unambiguous way ("sürgetőbb és komolyabb tennivalója, mint nyelvét lehetőleg közel vinni a szoros tudományok szabatosságához; mert csak oly nyelvvel, mely ehhez közelít, lehet aránylag legtöbbet legszaporábban saját érdeke körül felvilágosítni” (Széchenyi 1925: 160). It was important for him that language cultivation embraces every domain of language: vocabulary, morphology, and syntax: language cultivation - he writes creates words, smooths sentences, joins talking circles ("szókat gyárt, mondatokat simít, beszédköröket illeszt”). As politician and writer, he was concerned with the issue of definiteness and unambiguity of lexical meaning, as well as the communicational problems arising from linguistic deficiency. His starting point is that "linguistic deficiency is a defect" in every case when the meaning of the word is not clearly and categorically differentiated, and it becomes obvious only through "circumscriptio" (circumscription), as this causes "more or less disturbance". He is convinced that human welfare can be developed only based on pure concepts ("egyedül tiszta fogalmak alapján fejlődik ki az emberi jobblét”) (Széchenyi 1925: 153). He stressed in several of his works that erroneous concepts cause erroneous actions and this leads to "debauchery". That is why in his programmatic works he strives for precision in formulating: he differentiates the semantic nuances in synonyms; he also frequently describes a concept giving the corresponding words in several foreign languages (usually German, Latin, or French) when he senses that the Hungarian variant does not fully describe the notion.

He was also aware of the fact that the cultivation of the language can be achieved only as an integral part of the long-term processes of the rise of the middle class and of education, and as such it needs patience, perseverance, consistency, and persistence. He posed as an example before his contemporaries the diligence and perseverance of the Germans, who managed to elevate their literature from almost 
nothing in two thirds of a century and were able to form their social relations worthy to follow and to imitate in such a short time: "a Németnek szorgalmát és állhatatosságát, mely által kétharmad század alatt szinte semmiből fénybe tudta állítni literatúráját, s csak rövid idő alatt követésre, utánzásra méltóknak vala képes alakítni társasági viszonyait" (Széchenyi 1858: 92). He also warned against the Academy being an institution created by straw fire ("szalmatúz alkotta intézet"). He believed that a sophisticated, middle-class national literature is the manifestation of national characteristics expressed by creativity, its language representing the main features of the linguistic ideal: power in representation, brevity in expression, affluence in nuances of meanings, clarity and preciseness in expressing ideas, flexibility in creating sentences.

Széchenyi, one of whose most important objectives was the creation of "public rationality" (civil public sphere), realized that there is a strong relationship between the cultivated form of the language and the level of "social" (public) relations. One of his early diary entries (1820) refers to this: "Az angolok a társasági életet - ha az ember ismeri, és előítélet nélkül akarja mérlegelni, a tökéletesség lehető legmagasabb fokára emelték; honfitársaim viszont még a társaság szót sem értik." ("The English have raised social life - if one knows it and wants to assess it without prejudice - to the highest level of perfection; my compatriots, however, do not even understand the word social") (Széchenyi 1982: 191). Later, he publicly argues that in order to revive a nation there can be none other more rational act than the improvement of its language; this means that the language needs to be cultivated, polished, enriched, there is need to create the Hungarian variants for unknown linguistic expressions and styles. "[E] gyedül csak előleges, szorosan meghatározott definitiók következésében lehet nagyobb szövevényú fejtegetések- és vitatkozásokban aránylag könnyen vagy csak általjában is célhoz jutni, t. i. az igazságot teljes világba helyezni, s ekkép rábeszélni és győzni” ("only the primary, closely determined definitions allow for easy and general results in more complicated commentaries and debates, that is seeing the truth in a complete light, and thus persuade and convince") (Széchenyi 1925: 160).

He realized that the language is one of the strongest bonds linking the individual to a (language) community: "Anyanyelve első zengési, az ôt szülte föld első benyomási kiszakíthatatlan fogják lelkét éltén keresztül koporsóig bájolni" ("The first sounds of his mother tongue, the first impressions of the land where he was born will enchant his soul throughout his life to the grave.") (Széchenyi 1858: 151). He distinguished, even without naming them, languages that serve identity functions and those that serve communication. He believed that the mother tongue serves the maintenance and strengthening of identity, as the language is the soul of the nation which, if destroyed, can survive in servility, but without any life in it (Széchenyi 1858: 151). The guarantee to express the 
national characteristics is the free use of the mother tongue: "Nemzet, habár szabad alkotmánya van is, mindaddig, míg saját nyelvét nem használja, tovább áll a kifejlési lehetőségtől, mint a legvadabb nép, mely anyanyelvével szabadon él." ("As long as a nation, although it has a free constitution, does not use its own language, it is farther from the opportunity to develop than the most savage people who use their mother tongue freely.") (Széchenyi 1858: 216).

He criticized his fellow aristocrats who did not speak their mother tongue for being alienated from the nation. In his letter to Count Károly Esterházy (1828), he wrote: "midőn hazánkfiainak nagy része korcs, azaz se magyarok, se németek, se franciák, se angolok, stb., stb. Ez ám a mi nagy bajunk!" "“when most of our compatriots are hybrids, nor Hungarians, nor German, French, English, etc., etc. This is our big problem!”) (Széchenyi 2014: 88). He uses a pertinent metaphor when speaking about the role of the mother tongue in maintaining identity: the light of a "national spark of life" (nemzeti életszikra) shines on it; he also stresses that for a long time and with a few exceptions this spark only flickered under the soil, or was present exclusively in the narrow domain of sciences ("egyedül szalmafödelek alatt pislogott, vagy kirekesztôleg a tudományok szúk körére szorítkozék" - Széchenyi 1925: 162). He considered the general use of the Hungarian language in all areas of public life and in all social classes desirable. The cultivated language must rise to the community level as only through common traditions can it become an orientating pattern for the whole Hungarian language community.

\section{Multilingualism - plurilingualism}

His political activity made analysing the issue of multilingualism and plurilingualism inevitable. Széchenyi differentiated these two terms and used them consequently. When speaking about several languages and language varieties used in a certain geographical area, he used the term multilingualism: "Az Austriai birodalom a soknyelvűségnek s különnemzetiségnek legtarkabarkább példája." ("The Austrian empire is the most colourful example of multilingualism and different nationalities" - Széchenyi 1858: 59). He uses plurilingualism when talking about a given person's linguistic repertoire; for example: When travelling around Hungary, it is possible that if we do not speak four-five languages in addition to the developed European languages ("ha négy-öt nyelvvel az európai mivelt nyelveken kívül nem birunk"), the traveller will not encounter anyone to be able to talk to (Széchenyi 1858: 74). This distinction is noteworthy because the French-based terminology used in the European Council differentiates the two levels, while in the European Union, where English is the basis of conceptual thinking, only one term was introduced. 
Széchenyi considered multilingualism a historical given created by the geopolitical situation and historical conditions of Hungary. His position that every nation must be ensured to unperturbedly use their mother tongues was expressed several times and in various works. He considered the patient and permissive attitude not only fair and just but also practical. "Tiszteljük tehát akár mi kis körben létezőnek is nyelvét, s életmódját; mert a legkisebb elkülönözött emberi sajátság is egy karika azon lánczolatban, melynek fokain a tökéletesség felé emelkedik az emberi nem. Tiszteljük mindenkinek nem csak földi sajátját, de lelkének legnagyobb kincsét is 'honi, nemzeti húségét'! mert csak igy várhatunk mi is külön felekezetüek némi igazsággal sajátink, kincseink iránt türödelmet, engedéket" ("Let us respect the languages and way of life of those who are few; because the smallest differing human trait is also a link in a chain on which mankind rises towards perfection. Let us respect not only everyone's worldly properties but the greatest treasure of their souls, their loyalty towards their country and nation! It is the only way we, different peoples, can expect - with some right - tolerance and indulgence towards our own kind and treasures.”) (Széchenyi 1858: 69).

His conduct is based on philosophical foundations: he considered linguistic and cultural diversity to be of great value, the maintenance and cultivation of which he believed was a moral duty. In his words, every nation is invited to enrich humanity by exposing their own national features (Széchenyi 1858: 204).

He stressed the importance of this permissive, accepting attitude even when passionately arguing for making Hungarian the official language. "Beszéljen kiki, a hogy tetszik, a hogy tud, s ez iránt ne háborítsuk egymást; csak országos- s közdolgaink folyjanak egy hangon, egy nyelven" ("Everyone should talk as they like and can, and we should not disturb each other in this; only national and public matters should be carried out in one voice, one language.”) (Széchenyi 1858: 69). Only those are supposed to learn Hungarian who want to take part in public life ("ha az országos erőmüvbe befolyást venni akartok" - 'if you want to have an influence in the national power structure') (Széchenyi 1858: 69). He proclaimed the same principles after the Hungarian efforts were successful, and Hungarian was made official language in 1844; he also opposed propagating the language among non-Hungarian speakers. In his academic speech, he warned his contemporaries that speaking is far from feeling, that the movement of the tongue is far from the beating of the heart, and that those who speak Hungarian, eloquently as they may, are far from being Hungarian ("a szólás még korántsem érzés, a nyelvnek pergése korántsem dobogása még a szívnek, és ekkép a magyarul beszélő, sőt legékesebben szóló is, korántsem magyar még”) (Széchenyi 1925: 188).

Széchenyi linked plurilingualism to individual language skills, and interpreted it as a communicative competence created by several languages, as something that exists in several domains and as something that is characterized by the fact that linguistic knowledge is intertwined with cultural knowledge. 
He was born into bilingualism as the language of interaction in his family was German and Hungarian. Due to the conditions of the era and his social status, he learnt additional languages during his studies: French, English, Italian, and the mandatory Latin. The books he read (the classical masterpieces in the original language they were written in) and his travels (planning his trip to England with the purpose of practising the language and getting to know the culture from up close) formed his personal plurilingualism, which was enriched by every linguistic information and cultural experience, and within which the languages came into contact with each other.

In his conception, knowing several languages and cultures enriches the individual, increasing their knowledge, broadening their horizons, helping their orientation in the world, creating the ability to approach issues from several and different standpoints, thus enhancing a good judgement. Plurilingualism makes thinking more nuanced and encourages the writer to be accurate in language use, as sensing the "thousands and thousands of nuances" ("ezer meg ezer árnyéklatot”) between the languages, he needs to reflect on meanings. He also foresaw that in some way language shapes the world view of the speakers as the experiences about the world are fixed in linguistic forms and it is the language that makes their cognitive processing possible (Széchenyi 1858: 133). He also realized that the meaning of the same content can change depending on the language the utterance is formulated in: "A mi egyeneslelküséggel mondatik magyarban, az latán nyelvre lehető leghivebben áttéve már tán a keménynek szinét hordja magán, s a mi magyar erővel tétetik ki, az latánban tán már mint megbántás hangzik" ("What is said forthrightly in Hungarian when most faithfully translated into Latin can be sensed as tough and whatever is put forward with strength in Hungarian can be heard as an insult in Latin.”) (Széchenyi 1858: 134).

He considered developing this complex skill particularly important in the case of those who are involved in public life and especially politics. He examined the benefits deriving from plurilingualism from several aspects. He believed that the literacy acquired from plurilingualism can ensure presence in the European scientific and cultural discourses. He described America's example for his contemporaries, stressing that America owes its present situation to nothing else but the recognition and sensible application of other nations' experiences ("minek Amerika leginkább köszönheti mostani állását, s mi semmi egyéb, mint más nemzetek tapasztalásinak ismerése és józan alkalmazása”) (Széchenyi 1858: 241). He pointed out that in preparing a national "revival", it is practical to utilize the experience, knowledge, and results accumulated by developed nations; "ne mulasszuk el azon gyökérokok keresését, melyek nemzeti nagyságok sarkalati, mert máskép mindig homokra fogjuk állítni alaptalan müveinket” ('let us not miss the search for those roots that are the cornerstones of the great nations, or else we will permanently build our ungrounded creations on sand') (Széchenyi 1858: 240). 


\section{References}

Gergely, A. 1972. Széchenyi eszmerendszerének kialakulása. Akadémiai Kiadó, Budapest.

Tolcsvai, Nagy G. 2004. Alkotás és befogadás a magyar nyelv 18. század utáni történetében. Áron Kiadó, Budapest.

\section{Text editions}

Kovács, Henriett-Körmendy, Kinga-Mázi, Béla-Oplatka, András (eds). 2014. „Ezt köztünk! Isten áldja!” Széchenyi István válogatott levelei. MTA Bölcsészettudományi Kutatóközpont Történettudományi Intézet, Budapest.

Spira, György (ed.). 1991. Széchenyi István válogatott múvei I-III. Szépirodalmi Könyvkiadó, Budapest. Selection, editing, notes and endnotes by András Gergely (1799-1847), György Spira (1847-1851), Oszkár Sashegyi (1856-1860). Széchenyi, István. 1858. Hunnia. In: Töredékek Gróf Széchenyi István fennmaradt kézirataiból. Published by János Török, I. ed. Heckenast Gusztáv, Pest. 1979. Hitel. Pesten 1830. Facsimile. Közgazdasági és Jogi Könyvkiadó, Budapest.

Viszota, Gyula (ed.). 1925. Gróf Széchenyi István írói és hírlapírói vitája Kossuth Lajossal. I. (1841-1848). Magyar Történelmi Társulat (Magyarország újabbkori történetének forrásai). Budapest. 